УДК 39(497)(062)(049.3)

https://doi.org/10.55302/MF2179169d

Кристина Димовска

\title{
ХРОНИКА ЗА ХХ СИМПОЗИУМ ЗА БАЛКАНСКИ ФОЛКЛОР: „ФОЛКЛОРИСТИКА: ПРЕДИЗВИЦИ И ПЕРСПЕКТИВИ“
}

Апстракт: Трудот претставува ретроспективен преглед и коментар на презентираните материјали на XX Меѓународен научен симпозиум за балкански фолклор на тема: „Фолклористика: предизвици и перспективи“ во организација на Институтот за фолклор „Марко Цепенков“-Скопје. Симпозиумот се одржа на 22 и на 23 ноември 2019 година во хотелот „Континентал“ во Скопје.

Клучни зборови: хроника, XX Меѓународен симпозиум, балкански фолклор, Институт за фолклор „Марко Цепенков“, ретроспектива, коментар.

Важноста на фолклорот денес доаѓа посебно до израз, затоа што - за жал - се соочуваме со маргинализација на фолклористиката и на фолклористичките научни институции и дисциплини. Некогаш институција од посебен национален интерес, денес Институтот за фолклор „Марко Цепенков“ почива првенствено на наследените структури, потем на професионалната одговорност и доблест на неговите соработници, во услови на минимална финансиска поткрепа од државата.

Академик Катица Куулавкова, Сите лища на речта: беседи

Трудот претставува ретроспектива и рекапитулација на организацијата и на презентираните/претставени материјали/трудови на XX Меѓународен симпозиум за балкански фолклор на тема: „Фолклористика - предизвици и перспективи“, којшто се одржа на 22 и на 23 ноември во 2019 година во Скопје во организација на Институтот за фолклор „Марко Цепенков“. Симпозиумот се одржа во хотелот „Континентал“ во Скопје. Според официјалната програма, шесет и седум учесници презентираа свои трудови од кои само триесет и еден труд беа публикувани.

Симпозиумскиот организационен одбор беше составен од осум членови: во функција на претседател беше проф. д-р Родна Величковска, а во функција на членови: проф. д-р Зоранчо Малинов, проф. д-р Катерина ПетровскаКузманова, проф. д-р Лидија Стојановиќ-Лафазановска, проф. д-р Изаим Муртезани, проф. д-р Весна Петреска, проф. д-р Ермис Лафазановски и доц. д-р Кристина Димовска во функција на секретар.

Симпозиумот беше организиран во два дена. Првиот ден, односно на 22 ноември, беше одбележан со свечено отворање на Симпозиумот, проследен од поздравниот говор на директорот на Институтот за фолклор „Марко Цепенков“-Скопје, проф. д-р Ермис Лафазановски. Според официјалната програма, на првиот ден беа претставени 39 трудови од различни фолклористички области. И во првата и во втората сала во хотелот „Континентал“, успешно се одржаа вкупно осум сесии. На вториот ден, односно на 23 ноември, беа претставени 26 трудови поделени во шест сесии. 
Како резултат на успешната организација на XX симпозиум, Институтот за фолклор објави триесет и еден труд во списанието „Македонски фолклор“ бр. 77-78. Тука ќе стане збор за содржината и за значајноста на објавените трудови.

Во трудот „Краток преглед на теориите во фолклористиката од денешна перспектива“, проф. д-р Боне Величковски ја анализира состојбата во хуманистичките науки во последните децении на XX век, ставајќи го акцентот на кризата на позитивизмот, но и на напуштањето на т.н. „големи теории“ кои беа водечки не само во фолклористиката, туку и во сродните хуманистички дисциплини (во теоријата на книжевноста, антропологијата, теоријата на уметноста). Проф. д-р Величковски поаѓа од премисата дека идејата на неговиот труд не е да даде историски преглед на теории што ги тангираат погоренаведените хуманистички дисциплини, туку попрво да даде краток осврт на теориите што ја тангираат фолклористиката, со главен фокус на т.н. „антрополошка теорија“, актуелна од 1965 до 2007 година. Трудот е заокружен со констатацијата дека во современото време доаѓа до враќање на постмодернизмот односно на постмодернистичкиот третман на хуманистичките теми и прашања, како и на оживување на критичкиот став наспрема модернизмот.

Во трудот „Високообразовната дејност во Институтот за фолклор 'Марко Цепенков" во периодот 2008 - 2019 година“, проф. д-р Зоранчо Малинов ги сублимира активностите во областа на високообразовната дејност во посочениот период и овие се однесуваат на вториот и на третиот циклус на студии организирани во Институтот за фолклор „Марко Цепенков““. Овој труд е значаен затоа што ја проследува состојбата на високообразовната дејност во Институтот, меѓутоа она што му дава на „тежина“ или на кредибилитет, е фактот што авторот Малинов беше долгогодишен директор на Институтот (2011 - 2019) што го прави упатен не само декларативно туку и критички да ја коментира реалната ситуација со студиите од втор и трет циклус.

Во рамките на прегледот се дава увид во бројот на студенти што успешно ги одбраниле своите магистерски и докторски студии (12 магистри и 12 доктори по фолклористика). Заклучокот на трудот упатува на тоа дека Институтот за фолклор „Марко Цепенков“ и понатаму активно ќе продолжи да се занимава со исполнување на обврските во поглед на висоокобразовната дејност, со што не само што ќе продолжи да ја афирмира македонската фолклористика како дисциплина, туку и соодветно ќе обучи стручни кадри кои ќ го продолжат наследството на значајните истражувачи на македонскиот фолклор какви што се: акад. Блаже Ристовски, Лазо Каровски, Цветанка Органџиева, Танас Вражиновски и др.

Сепак, иако во трудов не се споменува, битно е предвид да се земе статистиката и моменталната состојба на студиите и студентите на системот за студентски сервиси „Ај ноу“ (“I Know”), којашто го отсликува реалниот степен на прогрес на студентите од втор циклус студии во исполнувањето на нивните студентски обврски и должности. Токму евиденцијата во овој систем укажува на потреба од поголема ажурност не само на стручниот кадар на Институтот, на запишаните студенти кои се водат како активни (кои 
пријавуваат и полагаат предмети, пишуваат научни трудови/ семинарски задачи, работат на својот магистерски труд), туку и на ресорните министерства кои мораат и се должни да изнајдат начини за стимулирање на образованието на идните стручни кадри од областа на фолклористиката.

Во трудот „Folkloristics and the challenges of defining its discipline: the relation of folkloristics and oral history“", авторката Абнора Души на своевиден начин се надоврзува на првиот труд во зборникот и ги истражува или, всушност, ги реактуализира прашањата што и до ден-денес се „спорни“ во фолклористиката. Како што авторката забележува, не е едноставно еднаш и засекогаш да се исцртаат и да се „фиксираат“ границите на истражувачкиот спектар на теми кои ја тангираат фолклористиката и кои се од нејзин (примарен, секундарен и терцијарен) истражувачки интерес. Светските фолклористи од калибарот на Дандес и Фолс, надолго и нашироко пишуваа на оваа тема, но она што го прави токму овој труд значаен и важен, е обидот да ја доведе фолклористиката во врска или во спрега со усната историја, преку означување на разликите во концептите и во методологиите на истражувањето. Во извесна смисла, текстот го потенцира значењето на теренските истражувања во теориска смисла, истакнувајќ́ ја важноста на бележењето на исказите на луѓето за настаните од минатото како дел од нивното сеќавање, но и зачувување/ документирање на колективната меморија на еден народ. Авторката заклучува дека преплетувањето на фолклористиката со усната историја, може да вроди или да понуди решенија на различни проблеми, со што истовремено ќе се постигне и понатамошно (до)развивање на овие дисциплини.

Во трудот „Потреба од терминолошки речник во фолклористиката“, проф. д-р Лидија Тантуровска ја истакнува потребата од потесна соработка меѓу лингвистите и фолклористите во обидите да се изнајдат соодветни терминолошки решенија коишто би биле прифатливи за двете страни и кои би придонеле не само за изнаоѓањ на посоодветни решенија за одредени „застарени“, архаични или странски термини, кои со децении се користат во фолклористиката, туку и изнаоѓање на заемен договор меѓу двете страни, кој нема да ги „крши“ правилата на стандардниот македонски јазик. Предлозите што ги нуди проф. д-р Тантуровска се темелат на нејзиното лично и непосредно искуство како долгогодишен лектор на списанието „Македонски фолклор“, така што таа е веројатно најповикана како лингвист не само да укаже на одредени двосмислености при дефинирањето и користењето на „Погрешни“ (односно несоодветни) термини од страна на фолклористите, туку и да понуди, онаму каде што е можно тоа, соодветни решенија, коишто нема да го изменат контекстот на одредено фолклористичко истражување. Впрочем, овој труд е значаен не само за списанието, туку и воопшто за науката, затоа што укажува на потребата од воедначен речник во трудовите коишто се занимаваат и третираат фолклористички теми. Сепак, за жал, степенот на интелектуална свест во Македонија е толку низок, што ова никако не би функционирало во практика. За да се коригира овој огромен, кобен недостаток, потребни се промени од корен, а за да дојде до овие промени, потребна е целосна смена на менталитетот и пристапот на македонскиот 
интелектуалец кон оваа проблематика. На хартија е лесно да се дадат насоките и да се заговара прогрес, но зборовите често се производ на индивидуално авторско перо, а за постигнување на напредок, потребна е колективна волја и напор во вистинската насока. Ако не се пишуваат и не се објавуваат трудови што разработуваат вакви суштински и неодминливи прашања, тогаш истражувачите нема да бидат и нема да станат свесни за потребата и можноста да ги коригираат (намерните или ненамерни) грешки во своите истражувања, без оглед на тоа дали се од лингвистички, од граматички или генерално од теориски аспект.

Во трудот „Challenges in folkloristics: a new understanding of the research object", авторката Леонтина Гега-Муса го проблематизира мултидимензионалниот пристап на фолклористиката при нејзиното интертекстуално (а би се рекло и интермедијално) преплетување со другите сродни хуманистички дисциплини, ставајќк го акцентот на: пристапите, методите и техниките на истражување на фолклорот во минатото, во споредба со денешните состојби во фолклористиката како дисциплина. Во трудот е даден краток осврт на фолклористичките истражувања (на искуствата, практиките и предизвиците) во Институтот за албанологија во Приштина. Но, авторката истовремено се надоврзува и на класичните сфаќања на поимот „фолклор“ и, условно кажано, завршува или го заокружува трудот со предизвиците во современото проучување на фолклорот. Трудот ги исцртува споделените точки коишто ја поврзуваат фолклористиката со науките какви што се книжевноста, етнологијата, социологијата, историјата и антропологијата. Секако, во денешно време, со огромниот раст и развој на технологијата, несомнено е дека врските што ги воспоставува фолклористиката со останатите дисциплини се развиваат уште подалеку, па така постојат истражувања на т.н. net-lore (или на интернет-,фолклорот“), на заемните врски и влијанија меѓу фолклорот и видеоигрите, на фолклорот и неврологијата (па и невропсихијатријата), што само дополнително докажува дека и покрај сите предизвици со коишто фолклористиката се соочува денес, таа сепак останува жива и актуелна иако, веројатно, не со интензитетот со кој се надеваат фолклористите.

Во трудот „Предизвиците на современите фолклористички и етнолошки истражувања“, проф. д-р Весна Петреска ги истражува и ги согледува, на сличен манир како и претходните трудови, глобалните промени што го одбележаа крајот на XX и почетокот на XXI век и како овие се одразија не само врз светската фолклористика и етнологија, туку и врз балканската фолклористика и етнологија. Почетокот на трудот ги истакнува дилемите за валидноста и издржаноста на дефинирањето на честоупотребуваните термини во фолклористиката какви што се: култура, народ, традиција, традиционално општество, нематеријално културно наследство, за во средината да посвети посебно внимание на сегашните состојби и текови во македонската фолклористика и на значењето (или поправо на улогата) на УНЕСКО при заштитата на културното наследство на Македонија, како идентитетски и обновлив економски ресурс. 
Во трудот „Народните обичаи при раѓањето на детето и во текот на првата година (врз примери од српската заедница во Нови Пазар)“, авторката Нина Аксиќ ги истакнува резултатите на истражувањата спроведени во проектот „Стратегије идентитета: савремена култура и религиозност“ („Стратегии на идентитетот: современа култура и религиозност“) финансиски подржан од Министерството за образование, наука и технолошки развој на Република Србија. Насловот јасно упатува на интерпретативниот интерес на трудот, кој се темели на теренски истражувања базирани на информациите добиени од соговорници/ информатори од Нови Пазар.

Во трудот „Откажување од наследството од женски аспект (причини, последици, чувства)“, авторката Наде Костадиновска-Спасеновска ги разработува аспектите на (материјалното) наследство и статусот на жената како наследничка (на имот). Според информациите што авторката ги нуди, истражувањето се спровело во Скопскиот Регион (односно во Горни Села и во населбите од општина Аеродром) и се собрале податоци од девет информаторки. Врз основа на добиените материјали, авторката укажува на разликата во поглед на наследството што се јавува кај постарата и кај помладата генерација (жени). Разликата, всушност, укажува и сведочи за генерацискиот јаз, кој ги дели бабите од внуките, па дури и мајките од ќерките, што следствено (или би се рекло природно) резултира и со смена на вредносните системи, но и со индивидуалната (женска) самосвесност кога е во прашање наследувањето и наследството во рамките на семејството и на фамилијата.

Во трудот „Кон пародијата на еден ритуал (според примерот на импровизираната свадба од с. Речане - Гостиварско)“, проф. д-р Изаим Муртезани се осврнува на ритуалот во форма на импровизирана свадба којашто се изведува на празникот Ѓррѓовден. Се проследуваат етапите на овој ритуал, кој, всушност, претставува реминисценција на трансвеститските епизоди од светската митологија: преоблекувањето на Ахил во женски алишта, преправањето на Тор во невеста и сл. Иако трудот се фокусира на конкретен пример од селото Речане, сепак истражениот материјал очигледно сведочи за поврзаноста на обичаите и практиките во минатото и денес, што дополнително укажува на сѐ уште живото постоење на реликти од прастарите, традиционални обреди. На овој ритуал, проф. д-р Муртезани му пристапува на две рамништа: 1) митско-антрополошки и 2) психоаналитички. Во рамките на првото рамниште ја истражува апликативноста на теориите на: Ван Генеп, Елијаде, Фрејзер, Купер, а додека во вториот - индиректно на Фројд и директно на: Бетелхајм, Дандес и Петрушевски.

Во трудот „Велигденски празнувања: традиција и современост“, проф. д-р Родна Величковска ги проследува обичаите поврзани за Велигден како најстар празник на христијанската црква. Имајќи го предвид долгогодишното работно искуство и професионален ангажман на авторката како етномузиколог, како и многуте спроведени теренски истражувања (главно) во Македонија од етномузиколошката област, логично е трудот да го става акцентот првенствено на изведувањето пригодни песни и ора за време на велигденските прослави. Проф. д-р Величковска во заклучокот на својот труд 
ја потенцира битната позиција што ја игра жената во традиционалната култура (а би се рекло и денес), особено од аспект на зачувувањето на старите обичаи и обреди (велигденски пости, обврски при крајот на аграрната година и сл.). Трудот е придружен со нотни прилози, кои би биле од посебен интерес за етномузиколозите, но и на оние фолклористи, етноорганолози, кои, макар површно или патем, ги разработуваат македонските песни и ора кои се исполнуваат за време на овој празник.

Во трудот „Gajda and zurna on the Balkans: development of differences inside national borders“, авторот Костис Драгијанакис се фокусира на користењето на гајдата и на зурната во различни балкански земји. Авторот констатира дека е речиси невозможно овие два музички инструменти да се заменат со кои било други иако, сепак, постојат региони, каде што нивната употреба е или сведена на минимум или пак е целосно исчезната. Битен податок е дека звучните записи, во кои се изведува музиката на овие инструменти, не секогаш се меродавни, затоа што го подразбираат посредството на снимателот и недоволно ја истакнуваат автентичноста на нивното изведување во руралните средини како нивна „матична“ средина.

Во трудот „Обредниот карактер на ороводните песни (избрани примери од Источното игроорно подрачје на Македонија)“, м-р Стојанче Костов дава теориска база за обредите и за обредните игри и нивното изведување во специфичен хронотоп. Авторот посветува внимание на терминот обред и на неговото сфаќање од етнокореолошки аспект, како и на битноста на вербалната димензија во ороводните песни, која е тесно врзана со традиционалното народно пеење. Теориската база е применета врз издвоени егземплари претставени низ песните: „Китче ми падна, бре, Величе“, „Мори Видо, неверна другачко“, „Тодоринко, баш именко“, „Овце пасе Маргита девојка" и др.

Во трудот „Zurna geography in Greece“, авторот Вагелис Баделас се надоврзува, во извесен степен, на трудот на Драгијанакис, со таа разлика што ги исцртува различните типови на зурна и диференцијациите што се појавуваат кај овој инструмент во различните грчки региони (Пелион, Арахова, Теба, Пелопонез, Мисолонги). Авторот истовремено истакнува дека инструментот каба зурна се среќава и во: Македонија, Албанија, Бугарија и Турција. Тој заклучува, слично на Драгијанакис, дека иако зурната е присутна како инструмент при изведбата во балканските региони, сепак, очигледни се трагите на нејзиното постепено исчезнување од употреба.

Во трудот „Стилови на изведување на инструментот канон, во државите, каде што е тоа традиционален инструмент“, авторот Тимко Чичаковски дава кратка историја на инструментот, негова етимологија, негово ширење и распространување низ светот (низ Франција, Италија, Турција, Македонија) и негова изведба како традиционален инструмент (во Ерменија, Азербејџан, Сирија, Ирак, Египет, Турција, Грција и Македонија). Тој посветува посебно внимание на перформансот во секоја од овие земји одделно. Во Македонија, канонот се изведува на сличен начин како во Турција (на т.н. „отомански стил“) и во Грција (на т.н. „византиски стил“). Чичаковски заклучува дека канонот како инструмент е значаен, и за да се избегне неговото исчезнување, 
инструментот би требало да се вклучи во образовните процеси, без притоа да се отфрли стариот стил на негова изведба.

Во трудот „Свадбениот обреден комплекс кај Македонците од Мала Преспа“, авторката Андријана Јаневска ја анализира свадбата како сложен обред од групата на обреди од животниот циклус, истовремено посветувајќи внимание на сите етапи на изведбата на свадбата, како и обичаите што се практикуваат во Мала Преспа. И во овој труд, како и во трудовите на проф. д$\mathrm{p}$ Величковска и на м-p Костов, истакната е незаменливата позиција и функција на жената во обредното пеење. Заклучокот упатува на тоа дека обредните обичаи и песни во овој регион се слични или речиси идентични со обредите и песните од целиот македонски ареал.

Во трудот „Меѓу традиционалното и современото: трансформацијата на репертоарот на македонските свадбени обичаи“, авторот Александар Димитријевски го надополнува трудот на Јаневска со тоа што ги истражува разликите во прославувањето и во одбележувањето на свадбените обичаи во минатото и денес. Покрај издвојувањето на свадбените етапи (традиционален свадбен циклус, подготовка за свадба, свадбени обичаи, постсвадбени обичаи и современ свадбен циклус), авторот Димитријевски посебно се задржува на анализата на музичкиот репертоар во современите македонски свадбени обичаи. Тој издвојува шест фази: во првата фаза вообичаено не се изведуваат обичаи врзани за музика, во втората фаза се „оди по невестата““ (проследено од песните: „Домаќине, добри гости ти дојдоа“, „Ерген одев, мајко“, „Еј, море, куме златен“" и др.), во третата фаза младоженците одат во матично (веројатно не се изведуваат музички нумери), во четвртата фаза венчавката се одвива во црква (и тука повторно не се изведува музика), во петтата фаза венчавката се прославува во ресторан (за сите инволвирани во свадбениот обред - невестата, младоженецот, кумот, старосватот, свекорот, итн. - се изведуваат посебни песни) и во шестата фаза се оди на т.н. „блага ракија“ (одбележана со песната „Ожени ме, мамо“). Заклучокот упатува на тоа дека меѓу традиционалниот и современиот обреден комплекс постојат сличности иако, како што би се очекувало, современите свадбени обичаи претрпеле и претрпуваат низа модификации, кои, најчесто, се и индивидуално зависни од учесниците во свадбениот обред.

Во трудот „Fеodotsy Rubtsov's contribution to comparative studies of the musical folklore of Slavs“, авторката Евгенија Редкова го анализира придонесот на ленинградскиот етномузиколог Теодосиј Антонович Рубцов, кој компаративно ги проучил споделените елементи на музичкиот фолклор кај: Македонците, Русите, Украинците, Бугарите, Полјаците, Србите и некои други народи. Трудот е збогатен со нотни примери од свадбени (македонски, бугарски и украински) и пригодни (коледарски) песни. Придонесот на Рубцов е значаен поради тоа што тој ја истакнал важноста на музичката модална структура, којашто, преплетена со структурата на музички фрази, го обелоденува процесот на формирање и идентификување на „интонацискиот речник“, „содржината на песните втемелена на интонацијата“ и „семантичката анализа на отсуството на пеење““. 
Во трудот „Орските и музичките содржини - уметничка потреба на свадбените прослави“, авторката Благица Илиќ ги проучува кратките традиционални орски и музички изведби во современите свадбени прослави, со што се надоврзува и своевидно ги „дополнува“ трудовите на претходноспоменатите автори, чии трудови беа од етномузиколошката или, поправо, од етнокореолошката област. Фокусот е на свадбените прослави во Скопје и во Гевгелија, при што се истражуваат сегменти од ора („Невестинско“, „Лесното-Правото“, „Тешкото“ и др.). Авторката истакнува дека свадбите имаат значење за социјалната заедница, особено од аспект на одржување на орската и на музичката традиција на Македонците и слично на авторот Димитријевски, таа забележува дека во последните 20 години (од 21 век) дошло до промени, како што е најмувањето на дувачки музички состави и музички тајфи од зурлаџиско-тапанџиски состав при свадбените прослави. Авторката исто така дава увид во своите лични искуства како непосреден набљудувач, но и организатор на свадбарскомузичка изведба и констатира раст на националното и идентитетското чувство кај Македонецот при изведбата на одредени бележити ора, какво што е „Тешкото“.

Во трудот „Ella von Schultz-Adaiewsky as a 'pioneer of ethnomusicology': discoveries of the XIX century together with modern practice“, авторката Ирина Теплова дава кратка биографија за животот на пијанистката, композиторката и етномузикологот Ела Шулц, чиј истражувачки влог ѝ ја доделил титулата на „пионер на европската етномузикологија“. Шулц посветила посебно внимание на музичката традиција во Резија (Италија), што всушност претставувало камен-темелник за нејзината понатамошна работа во истражувањето на музичкиот фолклор на: Британците, Чесите, Келтите, Татарите, како и на словенските племиња од Карнските Алпи. Шулц, користејќки го компаративниот метод на истражување во етномузикологијата, дошла до сознанија кои го специфицираат посебниот „музички јазик“ којшто е индивидуален и уникатен за различните народи што ги истражувала.

Во трудот „Историската важност на народните кажувања“, проф. д-р Вера Стојчевска-Антиќ отвора едно ново „поглавје“ во зборникот или, би се рекло, прави премост од етномузиколошките кон филолошките проучувања на фолклорот. Трудот се темели на теренското истражување на манастирот „Св. Богородица“, лоциран во Слимница, Преспанско, и посебно на наводното појавување на Богородица во овој регион. Авторката дава кратка историја за манастирот (неговото подигнување) и посебно се задржува на изјавите од информаторите, кои ја „виделе“ Богородица „во живо“. Сепак, насловот го изневерува читателскиот хоризонт на очекување затоа што во трудот не станува збор за дијахрониско проучување на историските кажувања, туку за проследување на низа информации добиени од соговорниците кои се поврзуваат со необјаснивиот феномен на појавата на Дева Марија „in vivo“ во споменатиот манастир.

Во трудот „Некои карактерни и физички особини одразени во македонските народни поговорки и пословици“, авторот Иван Котев набројува поговорки и пословици тематски структурирани во категориите: „безобразие и безоблирност“, „благодарност и човечност“, „клеветење и 
клетви“, „вистина и лага“, „властољубивост и аривизам“, „вообразеност“, „давање и земање“, „Дволичност“, „достоинство“ и др. Паремиолозите се свесни дека класификацијата на кратките жанрови, какви што се овие содржани во насловот на трудот, не е невозможна, но не е едноставна, посебно затоа што истражувачите (кои не секогаш мораат да се занимаваат со паремиологија или само со паремиологија) не можат да постигнат консензус кој начин и кој пристап е најдобар за нивна класификација. Трудот на Котев прави обид да ги структурира поговорките и пословиците во тематски единства, со што се добива на јасност и компактност, и акцентот не е ставен примарно на поговорките и пословиците, кои ги истакнуваат негативните својства на луѓето, туку се истакнуваат и позитивните човекови особини, така што текстот се развива низ антитетични примери на различните тематски единства. Како таков, трудот е особено полезен за проучување на поговорки и пословици, кои се недоволно познати (во смисла дека не се користат често во усната комуникација) и со тоа е даден еден мал архив на овие кратки жанрови.

Во трудот „Семантичкиот поттекст на локалната сказна во сооднос со универзалниот модел на сказновидната матрица (врз примери од необјавената книга Араптази - волшебни народни приказни од Струмица и Струмичко) од Иван Котев“, авторката Ана Витанова-Рингачева прави извесен омаж на 50годишната заложба, труд и придонес на Иван Котев не само во собирањето и дешифрирањето на фолклорните материјали од Струмица и од Струмичко, туку и во нивното конзервирање и претворање во наследство за идните генерации (на читатели, но и на истражувачи). Дадена е теориска база за мотивите што се среќаваат во избор на волшебни приказни (сказни, според авторката), имено во „Детето јунак и Арапино“ и „Рокчето“ од (сега веќе објавената) книга на авторот Котев. Посебно се разгледани етапите на обредот на премин (иницијацијата на младиот јунак), но се образложуваат, иако со различна терминологија, некои етапи од Кембеловиот мономит (главно помошта што јунакот ја добива во својата авантура и неговата привремена [симболичка] смрт). Експозето на Витанова-Рингачева на симпозиумот претставуваше извесна претпромоција на книгата Араптази, и во списанието „Македонски фолклор“ бр. 77-78 за првпат беа објавени двете погореспоменати волшебни приказни, со што како да се најави успешната публикација и на останатите волшебни приказни собрани и запишани од Иван Котев под насловот Араптази.

Во трудот „Чудноприказната на Џон Толкин“, доц. д-р Кристина Димовска пристапува кон проблемот на две рамништа, коишто меѓусебно се испреплетуваат и се надополнуваат. На првото рамниште се истражуваат врските меѓу хипотекстот и хипертекстот (термини на Жерар Женет), а на второто рамниште се коментираат и се интерпретираат паремиолошките форми во Чудноприказната (Woundrous tale) на авторот Џон Толкин и во анонимниот, англосаксонски еп Беовулф. Џон Толкин имал извонредна шанса, како преведувач од англосаксонски на современ англиски јазик, да го преведе епот Беовулф и со тоа да го направи епот достапен (поразбирлив) за поширок круг на читатели. Неговиот влог е исто толку голем и значаен како потфатот и влогот на професорот Драги Михајловски, во свој манир, да го транспонира 
епот на македонски јазик. Иако обата текста нудат ограничен опсег на паремиолошки форми, тие сепак се соодветни за истражување на кратките жанрови кои го доловуваат (или го доближуваат) херојскиот етос во 21 век, како век во кој самото поимање на терминот „херој“ и „херојство“, е видоизменет, модифициран и понекогаш конфузен.

Во трудот „Предизвикот на визуелното изразување и неговите перспективи низ призмата на меѓународниот фестивал на етнолошки и на документарни филмови во Кратово“, авторката Елизабета Конеска дава осврт или прави ретроспектива на IX Меѓуународен фестивал на етнолошки документарен филм „Кратово 2020“, којшто се одржа од 2 до 4 октомври 2020 г. Авторката наведува дека Меѓународниот фестивал постои од 2012 година, а на веб-порталот на Македонското етнолошко друштво, е достапна програмата во којашто се споменати имињата на сите режисери што се претставија со свои кратки филмови (со потекло или престој во: Македонија, Бугарија, Хрватска, Ирска, Франција, Италија, Јапонија, Русија, Мароко, Украина, Унгарија и др.). За време на дводневното одржување на фестивалот, претставени беа 24 филмови, а режисерот Давор Бориќ и Лилјана Шишмановиќ, беа издвоени како најредовни автори на репертоарот на Фестивалот во изминатите неколку години. Трудот не само што ги дава генералните податоци за деветтиот, по ред, меѓународен фестивал, туку исто така укажува на актуелната состојба со организацијата на фестивалот, потенцирајќи ги неповолните услови за негово оптимално функционирање, како што се: осиромашувањето на општествата, лошиот образовен систем, општата атмосфера на криза во културата, ограничениот опсег на учесници и изгубениот социјален аспект врзан за ваквите собири. Авторката нуди можни решенија за подобрување на ситуацијата: обезбедување на поголема (или би се рекло поквалитетна) медиумска кампања, подобрување на меѓуинституционалната соработка, вклучување на нови членови во организацијата и, веројатно најглавното, обезбедување на соодветна финансиска поддршка од ресорното министерство.

Во трудот „Фолклорот и неговиот прототеатарски импулс“, авторката Ана Стојаноска ја интерпретира битовата драма преку теориско елаборирање на прототеатарските елементи содржани и присутни во фолклорот. Македонската фолклорна традиција составена од најразлични жанрови почнувајќи од песните и приказните, па сѐ до преданијата и соништата - има богат потенцијал да се „премости“ во театарот и да добие своја интерпретација во согласност со моделите на функционирање на театролошката поетика. Таа посветува време на дијалогичноста и на театралноста на фолклорот, го анализира етнотеатарот, ја исчитува македонската битова драма преку нејзината испреплетеност со фолклорот низ две фази или нивоа: иманентно (Чернодрински, Молеров, Цепенков, Брадина и Крстиќ) и напредно ниво (Иљоски, Крле и Панов). Заклучокот упатува на тоа дека традицијата може да се искористи како подлога за т.н. „театралика“ на една земја, а прототеатарскиот импулс на фолклорот е издигнат на повисоко ниво (со што добива свое заслужно место) и станува важен за поттикнување на едукацијата и на креативноста кај неговите спектатори. 
Во трудот „Присвојување на кодовите од минатото и нивно постмодернистичко извртување“, авторката Биљана Рајчинова-Николова ги сопоставува идентитетот и другоста низ призма на реалните општественоисториски услови кои ги обликуваат како личниот, националниот и колективниот идентитет, така и културата, религијата и идентитетот на Другиот (како различен од нас). Текстот ја истражува хипотезата дека претставата и поимањето на Другиот, може да се первертира од причина што неговиот статус не е детерминиран, туку попрво претставува, како што смета авторката, вокација и провокација, а во неговото сфаќање улога игра и машкоженската љубов, која ги нивелира разликите, разидувањата и несогласувањата меѓу припадниците на различни религии. Хипотезата се докажува преку интерпретација на овие категории во драмите Македонска крвава свадба од Чернодрински и Балканот не е мртов од Дуковски.

Трудов, кој инаку е од областа на културологијата, дава теориска рамка за докажување на хипотезата преку аналитичкиот и компаративниот метод, правејќи го тоа преку анализа на тројството „религија, идентитет и љубов“ и преку религиски кодираната статична ортодоксност наспрема религиски кодираната динамична рефлексивност. Авторката заклучува дека Балканот не е мртов претставува лично-уметничка визија на Дуковски за Македонска крвава свадба на Чернодрински и како таква е проткаена со: иронија, монтажа, рециклажа и травестија. Заклучокот, всушност, не претставува исцрпување на согледбите за овие две драми по однос на анализираните категории, туку поттикнува понатамошни (и мошне актуелни) прашања и дилеми како најправилно да му се пристапи на Другиот во време на општа нетрпеливост која очигледно стана една од негативните константи на современиот живот.

Во трудот „Фолклорната естетика во револуционерноангажираната драма од крајот на XIX век и на почетокот на XX век“, авторката Славица Петровска ги сумира теориските сознанија за историскиот развој на драмските дела низ кои се препознаваат суштинските насоки на: духовниот, естетскиот и книжевниот развој на епохата што е истакната како предмет на анализа. Трудот посветува внимание на народната мудрост сочувана во драмите на: Чернодрински, Цепенков, Молеров, Хаџидинев и др., со посебен фокус на паремиолошките форми (поговорките, пословиците, благословите и клетвите). Според авторката, револуционерноангажираната драма од крајот на XIX век и почетокот на XX век, на прв план го става националниот и културниот развој на македонскиот народ, а овие процеси биле (и до денешен ден се) под влијание на комплексните промени во духовниот и во културниот живот на Македонците.

Во трудот „Црквата 'Рождество на Пресвета Богородица' во Тепавци како поствизантиски антецедент на преродбенските трикорабни базилики“, авторката м-р Емилија Апостолова-Чаловска ги претставува резултатите од сопственото, теренско истражување спроведено во Битолско, Мариово, и ја анализира архитектурата, архитектонската типологија, конструкцијата и декорацијата на споменатата црква. Целта на ова е да се истакнат влијанијата што одиграле улога врз нејзиното настанување. Овој труд претставува добар 
пример дека на симпозиумите што ги организира Институтот за фолклор „Марко Цепенков“ (кои вообичаено се одржуваат на секои две години), се претставуваат теми што се актуелни и во областа на народната архитектура, која е, секако, битен дел од фолклорното наследство на македонскиот народ. Трудот не само што подробно ја анализира црквата „'Рождество'... “, туку исто така нуди и ретки прилози (основа, напречен и надолжен пресек на црквата, основа на други цркви, какви што се „Св. Никола“ во Мирковци, „Св. Никола“ во Глуво, „Св. Софија“ во Охрид, „Успение на Пресвета Богородица“ во Велушина и др.) и компаративно ја проучува црквата „,Рождество'... “ низ нејзините сличности и разлики со поствизантиските трикорабни базилики. Авторката ја изделува оваа црква како редок пример на постари градби и како извонредно значаен споменик поради тоа што ги поврзува преродбенските базилики од XIX век со нивните средновизантиски и ранохристијански антецеденти.

Во трудот „Антропологија на мултикултурализмот: теорија и практика“, авторката Мирјана П. Мирчевска третира актуелна и современа тема и нуди дефиниции на термините, какви што се: „етнички идентитет“, „културен идентитет“, „етницитет“, „мултикултурна политика“ и др. Дефиницијата и сфаќањето на терминот „мултикултурализам“ предизвика конструктивни дебати на еден друг симпозиум, којшто исто така беше организиран од Институтот за фолклор „Марко Цепенков“ и од Македонското етнолошко друштво, а се одржа во Кратово на 26 и на 27 септември 2019 г. Темата беше посветена токму на мултикултурализмот: „Етнолошки и фолклористички аспекти на мултикултурализмот и интеркултурализмот на македонското општество“, каде што и авторката Мирчевска зеде учество.

Во трудов за кој станува збор, мултикултурализмот е дефиниран како идеологија, како сложен и повеќеслоен феномен, како збир на активности и практики присутни во етнички, религиски и културнокомплексни општества, како нова кованица, која ѝ оддава признание на културната разновидност. Меѓутоа, во современите општества не станува збор толку за мултикултурализам колку за мултикултурализми и низ дел од нив се потенцира релативистичката толеранција на обичаите и на верувањата на „другите“, а со оваа констатација, текстот има допирни точки со ставовите изнесени од авторката Рајчинова-Николова. Авторката Мирчевска ги осудува или, поправо, ги отфрла настојувањата на поборниците за мултикултурализмот да ги прифатат меѓучовечките разлики, од причина што оваа идеологија, како своевиден „проект“, се покажа неспособна соодветно и ефикасно да одговори на современите проблеми поврзани со идентитетот и културата и која исто така промовира сегрегација на културата, создава двојни општествени вредности и двојни или паралелни општества во една држава.

Во трудот „Социјално-економските аспекти во фолклорот на македонските Евреи“, авторот Владимир Јанев дава кратка историја на општествените, социјалните и економските аспекти коишто условиле кај македонските Евреи да се создадат и да циркулираат фолклорни творби какви што се: кратките приказни („Козата и теснотијата“, „Седумте бедни години“, „Писмото на Перахија“, „Џуха и семето од камили“ и др.), песни („Станувај, 
еврејска младино“, „Ерусалим“ и „Благословен“), и пословици од Битола (категоризирани како поговорки од авторот). Трудот е богат со примери од овие жанрови, кои се посебно значајни за паремиолозите.

Последниот, но не и помалку значаен труд во списанието, е трудот „Селскостопански објекти во етничкиот предел Кривопаланечко“ на авторот Боре Неделковски, во кој се даваат називите и се објаснуваат функциите на селскостопанските објекти какви што се: амбарот, плевната, шталата, кошот, трлото, кочината, кокошарникот, казаницата и др. Авторот описно, но и преку фотографии, ги документира и ги објаснува функциите на објективе. Трудот е значаен затоа што ќе остане во ризницата на текстови објавени во списанието „Македонски фолклор“ во кои фигурираат, некој би рекол, архаични термини или барем термини што не им се познати не само на некои (помлади) истражувачи на фолклорот (во Македонија и особено надвор од неа), туку и на голем дел помлади припадници на генералната јавност. Во време во кое македонскиот јазик е во постојана криза (поради легитимни или нелегитимни политички причини, основани или неосновани манипулации со јавноста преку медиумите, но уште повеќ и поради катастрофалниот образовен систем во Македонија), трудовите каков што е овој, во кој се претставуваат и се коментираат објекти, кои, за некои луѓе, веројатно претставуваат дел од далечното минато, служат како потсетник дека јазикот во себе содржи меморија и дека одредени термини, без оглед на тоа што не се употребуваат секојдневно или често во усната комуникација, сепак се дел од таа јазична (и не само јазична) меморија, која мора да продолжи да се пренесува и на генерациите што доаѓаат, без оглед на тоа какви (социјални, културни, технолошки) промени и да се случат на светско ниво.

Од сето што досега беше изложено може да се заклучи дека XX симпозиум за балкански фолклор, во организација на Институтот за фолклор „Марко Цепенков“-Скопје, во бројот 77-78, понуди богат репертоар на трудови од различни научно-истражувачки области, со што поттикна (и и понатаму ќе поттикнува) некои нови и некои стари сознанија, кои сѐ уште се испитуваат. Разновидноста на трудовите, од тематски аспект, сведочи за сѐ уште живиот интерес за (македонскиот, балканскиот, светскиот) фолклор, но за да продолжат и понатаму да се организираат вакви симпозиуми, сосема е јасно дека е потребно уште повеќе да се засили интересот за (интердисциплинарно) проучување на фолклорот во Македонија за да се запре, ако е возможно тоа, неговото замирање.

\section{ЛИТЕРАТУРА}

ДИМОВСКА, К. (гл. ур.) (2020) Македонски фолклор. Год. LI, бр. 77-78. Скопје: Институт за фолклор „Марко Цепенков“ - Скопје.

КУЛАВКОВА, К. (2020). „Промотивна реч за Избраните дела на Блаже Ристовски во 10 тома“. Во: Сите лища на речта: беседи. Скопје: МАНУ, 6165. 


\title{
Сајтографија
}

\subsubsection{1].}

http://www.makedonskoetnoloskodrustvo.org/en.html [Пристапено

на

Kristina Dimovska

\section{REVIEW OF THE PAPERS PRESENTED ON THE XX INTERNATIONAL SYMPOSIUM ON BALKAN FOLKLORE}

\begin{abstract}
Summary
The paper focused on the significance of the 31 published papers which were presented on the XX International Symposium on Balkan Folklore on the topic: "Folkloristics: Challenges and Perspectives" organized by the "Marko Cepenkov" Institute of Folklore in Skopje. The symposium took place on 22-23 ${ }^{\text {rd }}$ of November 2019 in Skopje, in the hotel "Kontinental".

In vol. 77-78 of the journal "Macedonian Folklore" published by the Institute, 31 (out of 67) authors have contributed with their research: Bone Velichkovski, Zorancho Malinov, Abnora Dushi, Lidija Tanturovska, Leontina Gega-Musa, Vesna Petreska, Nina Aksikj, Nade Kostadinovska-Spasenova, Izaim Murtezani, Rodna Velichkovska, Costis Drygianakis, Stojanche Kostov, Vagelis Badelas, Timko Chichakovski, Andrijana Janevska, Aleksandar Dimitrijevski, Evgenia Redkova, Blagica Ilikj, Irina Teplova, Vera StojchevskaAntikj, Ivan Kotev, Ana Vitanova-Ringacheva, Kristina Dimovska, Elizabeta Koneska, Ana Stojanoska, Biljana Rajchinova-Nikolova, Slavica Petrovska, Emilija ApostolovaChalovska, Mirjana P. Mirchevska, Vladimir Janev and Bore Nedelkovski. The papers show the still ongoing interest in folklore analysis from different fields: paremiology, literature/literary science, ethnomusicology, ethnoorganology, folk architecture, folk customs etc and this is a testimony that folklore and its research is still active in Macedonia thanks to the researchers that contribute with their interest, presence on symposiums such as this one and will to continue to expand the interest in folk research (in Macedonia, on the Balkans, but also worldwide). This proves that folkloristics is still active as a discipline, although this does not mean that further efforts should not be made (by the government, by the ministries, by the similar institutions etc).
\end{abstract}

